\title{
PREFACE TO THE SECOND EDITION Then and Since
}

This twentieth anniversary edition provides an opportunity to look backward to my writing of The Bonds of Womanhood and forward from it to other historians' subsequent attention to the meaning of domesticity and "woman's sphere." The project really originated in 1972, when I was finishing a collection of documents in United States women's history, Root of Bitterness, and was formulating my doctoral dissertation. Both the anthology of documents and the method of the dissertation shared a common emphasis on finding the personal "voices" of nonfamous women of the past in their untapped private writings. ${ }^{1}$ In the women's movement of the previous several years I had, like hundreds of thousands of other women, reeducated myself by discovering new intellectual premises that made it possible to see women as subjects in history (and agents of change) as never before. To locate women as subjects, no sources seemed more promising-less tainted by stereotypes or unwarranted assumptions about femininity-than the ones women had penned for themselves and to other women.

My assumptions owed a great deal (more than I recognized at the time) to the emphasis on women's consciousness and on "consciousness-raising" in the women's liberation movement, of which I felt myself a part. Consciousness-raising was

1. I completed my dissertation in 1974. Root of Billerness: Documents of the Social History of American Women was first published by E. P. Dutton in 1972. I have recently collaborated with Jeanne Boydston, Ann Braude, Lori D. Ginzberg, and Molly Ladd-Taylor on a thoroughly revised-indeed almost entirely new-edition of this anthology, published under the same title by Northeastern University Press, 1996. 
a political strategy: in all-female groups, women shared reflections on their lives, with the intent to recognize and confront the ways that they had been taught to be "women" (that is, to conform to the gender expectations and constraints that created sexual inequality). The aim was to undermine or throw off one's socialization and change the structures that maintained it. The heady dynamic of consciousness-raising made me very interested in questions about consciousness in the past: had women been aware of themselves as women, and how had they been aware? The likeliest place to discover answers seemed to be in private writings.

An important historical question motivated my research, too, and that had to do with the efflorescence of didactic writings about womanhood and family life in the urban northeast of the United States in the 1820s and 1830s. When I began my project, historian Barbara Welter had already discerned an antebellum "cult of true womanhood" and Aileen S. Kraditor a "cult of domesticity" (the term I preferred, because it went beyond insular consideration of women's roles to include all family members). The motivation for this cultural phenomenon centering on families was not clear to me, however, nor had historians adequately explained the part played by the very women addressed and described in didactic writings. Women appeared dictated to, the objects of social prescription. ${ }^{2}$

Schooled in the new social history's emphasis on specifying class and community, I decided to focus on middle-class women in New England, where so much of the writing on women's place in the home was produced, and to begin not in the 1830s but a half-century earlier. My approach was in-

2. See Barbara Welter, "The Cult of True Womanhood, 1820-1860," American Quarterly 18 (1963), 151-74, and Aileen S. Kraditor, Up from the Pedestal: Selected Writings in the History of American Feminism (Chicago: Quadrangle, 1970). Neither in recalling here what works influenced me, nor in mentioning works on related themes following mine, am I trying for comprehensiveness; this essay is a very selective and idiosyncratic historiographical review. 
formed by feeling that the first as well as the second half of Marx's memorable dictum, "Men make their own history, but they do not make it just as they please," ought to apply to women, too. ${ }^{3}$ I figured that if the cult of domesticity had been quite widespread, then women could not have been only its dupes or victims but must have participated in creating it, even if not controlling its extent or consequences. (The same conviction led me to investigate the origins of nineteenth-century belief in women's "passionlessness," which was the first item I puzzled through in my dissertation, in 1972; I separated that chapter from The Bonds of Womanhood, however, and did not publish it until the late 1970s.) ${ }^{4}$ Just as the emphasis on consciousness in the women's movement drew from a deep well of socialist thinking and organizing around class consciousness, my insistence on seeing women, however subordinated, as active shapers of their own circumstances was ineffably influenced by the socialist historian E. P. Thompson's The Making of the English Working Class, in whose huge shadow the new social history and feminist history grew up. ${ }^{5}$

My aim, then, was to see how middle-class women's experience and concomitant outlook in the decades leading toward the 1820s anci 1830s matched or confronted (or possibly produced) the prescriptive "canon" of domesticity,

3. Marx is referring, of course, to the weight of history, continuing "they do not make it under circumstances chosen by themselves, but under circumstances directly found, given and transmitted from the past." The Eighteenth Brumaine of Louis Bonaparte (New York: International, [1935]), p. 13.

4. "Passionlessness: An Interpretation of Victorian Sexual Ideology, 17901850," Signs 4:2 (1978), 219-36.

5. Edward P. Thompson, The Making of the English Working Class (New York: Pantheon, 1963). I was also educated by socialist-feminist historians influenced by Thompson, notably Mari Jo Buhle, Ann G. Gordon, and Nancy Schrom, "Women in American Society: An Historical Contribution," Radical America 5:4 (July-August 1971), 3-66, and Juliet Mitchell, "The Longest Revolution," New Left Review (November-December 1966) and Woman's Estate (New York: Pantheon, 1971). 
as I came to call it. ${ }^{6}$ I began with women's work, assuming some priority for economic causation, for I was investigating a period of thoroughgoing economic change that affected both sexes and all ages. Women's diaries and letters revealed to me what looked like a constant in the midst of change: married women's main work remained in the household while its productive scope, especially in urban locations, contracted. Following Thompson's distinction between the traditional task-orientation of preindustrial work and the rigid requirements of time-disciplined capitalism, I found this persistence of married women's task-oriented household occupation to be signally important, the emblem and engine of categorical differentiation of women, as a group, from men. ${ }^{7}$ As I researched and wrote, I was struck by the ways in which not only economic change but also cultural authorities, particularly educators and ministers, unintentionally conspired to make gender visible as a social classification, thus refashioning womanhood as a social role. Women's own sense of who they were was undergoing social reconstruction. In my reading of the evidence, if most women were properly constrained by new awareness of what a "woman" should be and do, others were able to make unanticipated uses of this conviction.

Looking back now, I realize that I was riveted on issues of these middle-class white women's consciousness-how they thought about themselves in relation to men and to the rest of their world, in analogy to what was transpiring among middle-class white women around me at the time. I considered it crucial to trace the developing awareness among this group of women that they were "classed by sex." (It was, of

6. Kathryn Kish Sklar's magnificent biography Catharine Beecher: A Study in American Domesticity (New Haven: Yale University Press, 1973) appeared while I was writing, and established Catharine Beecher's major role in envisioning and publicizing values of domesticity.

7. E. P. Thompson, "Time, Work-Discipline, and Industrial Capitalism," Past and Present 38 (1967). 
course, a tenet of women's liberation of the period that such awareness was a precondition for feminism.) To put it another way, I was pursuing the insight with which Amy Dru Stanley opens a 1996 essay: "What we know as the market revolution posed a momentous moral problem that contemporaries, in the first instance, understood as a problem of gender." I proposed that men and women trying to make sense of their transformed world engineered an ideology of gender, and one of its consequences was to educe "womanhood" as a social role as well as a sexual category.

Although readers haven't always agreed, I have always seen the heart of the book to be the second chapter, which analyzes the uses and contradictions of the constellation of ideas and practices called "domesticity." Re-reading The Bonds of Womanhood today, I see it as asserting that a discourse of domesticity was established in this time period. In the early and mid-1970s I was not cognizant of this sense of discourse (derived mainly from Michel Foucault); I was, however, trying to capture the ways that ideology and experience were reciprocally influential or mutually constitutive. ${ }^{9}$ Now I can take advantage of the concept of discourse, especially as presented in Gail Bederman's very clear yet subtle definition:

8. Amy Dru Stanley, "Home Life and the Morality of the Market," in The Market Revolution in America, ed. Melvyn Stokes and Stephen Conway (Charlottesville: University Press of Virginia, 1996), p. 74.

9. The subtitle of my dissertation was "Perspectives on Female Experience and Consciousness in New England, 1780-1830." My notion of experience was indebted to E. P. Thompson, whose approach Joan W. Scott has elegantly summed up (in order to reject it): "Thompson specifically set out to free the concept of 'class' from the ossified categories of Marxist structuralism. For this project 'experience' was a key concept. His notion of experience joined ideas of external influence and subjective feeling, the structural and the psychological. This gave Thompson a mediating influence between social structure and social consciousness. For him experience meant 'social being'-the lived realities of social life, especially the affective domains of family and religion and the symbolic dimensions of expression." Joan W. Scott, "Experience," in Feminists Theorize the Political, ed. Judith Butler and Joan W. Scott (New York: Routledge, 1992), p. 29. 
"a set of ideas and practices which, taken together, organize both the way a society defines certain truths about itself and the way it deploys social power." As Bederman points out, such a concept of discourse gets beyond-really disavowsthe Marxist-derived distinction between (material) base and (superstructural) ideology. Thinking in terms of discourse means assuming that ideology and institutions, beliefs and "social realities" (Foucault himself stressed knowledge and power) are necessarily intermeshed. Although some historians shy away from the notion of discourse as overly determining of human actions, ideas and practices identifiable as a discourse wielding and representing social power should not be assumed to be seamless or utterly consistent, as Bederman emphasizes. Rather they are inevitably internally contradictory, somewhat ambiguous, and variously deployed. That ambiguity or inconsistency leaves open the possibility for slippage, for resistant interpretations, for shifts, or for seizing of opportunities by individuals, which may reorder power relations. ${ }^{10}$

Using such a definition, I think it makes sense to speak of domesticity as a discourse in nineteenth-century America, both a cardinal value and a daily practice of the prosperous and property-owning classes, the instigators and main bene-

10. Gail Bederman, Manliness and Civilization (Chicago: University of Chicago Press, 1995), p. 24. See Michel Foucault, The History of Sexuality, vol. 1 (New York: Vintage Books, 1980), pp. 100-102. Certainly many historians have recognized the inextricability of ideas and practices, or ideology and institutions, without using the term discourse, as for instance Gordon Wood's comment that the "collective cultucal system that we have assimilated, consciously or unconsciously, suffuses all parts of our mind and in effect creates our behavior. It does so by forcing us to describe that behavior in its terms. Our actions tend to be circumscribed by the ways we can make them meaningful ... with respect to an inherited system of social rules, conventions, and values." "Intellectual History and the Social Sciences," in New Directions in American Intellectual History, ed. John Higham and Paul Conkin (Baltimore: Johns Hopkins University Press, 1979), p. 35. 
ficiaries of "the market revolution." 11 By the discourse of domesticity I mean the ideological presumptions, institutional practices, and strongly held habits of mind insisting that the home must be guided by a calm, devoted, and self-abnegating wife and mother: that with her presence, the home would serve-and it had to serve, for social order and individual well-being - as a moral beacon, a restorative haven from the anxieties and adversities of public life and commerce, comforting the hardworking husband and provider for the family, and furnishing a nursery of spiritual and civic values for the children. The Bonds of Womanhood outlined how gender conventions were embodied in the discourse of domesticity, and how the discourse purveyed gender meanings. It focused on women rather than on how individuals of both sexes and all ages were involved. In the two decades since I wrote the book, I have thought a good deal more about the ways that domesticity ensnared men, too, as well as empowering them, shaping a ruling definition of manliness around the provider role to be taken by the husband/father. Questions like this have begun to be explored as a result of many feminist scholars' emphasis that gender, as a system of meanings given to sexual difference, is always relational, defining female in relation to male, femininity in relation to masculinity. ${ }^{12}$

I now think of domesticity as a discourse through layers of subsequent scholarship that have vivified and enriched

11. I began to re-view domesticity in this light in 1992, when I was asked to contribute the entry on it for A Companion to American Thought, ed. Richard Wightman Fox and James Kloppenberg (Cambridge: Basil Blackwell, 1995); some of my language here is taken from that entry. Note Charles Sellers' confident assertion, in The Market Revolution: Jacksonian America, 1815-1846 (New York: Oxford University Press, 1991), p. 237: "The so-called middle class was constituted not by mode and relations of production but by ideology."

12. A pioneering work was Charles Rosenberg, "Sexuality, Class and Role in 19th-Century America," American Quarterly 25 (May 1973), 131-53; more recent 
my original thinking-dialectical exchanges among historians that show domesticity to have been, in fact, a more powerful discourse and one with more ramifications than I realized at the time I first investigated the subject. A number of important works following The Bonds of Womanhood that were more keenly attuned to class formation and conflict established the view that the discourse of domesticity was a prime means by which members of the ascendant middle class understood themselves as men and women and presented themselves to the world. Mary P. Ryan's influential Cradle of the Middle Class (1981), a fine-grained community study of economic, religious, communal, and family activities in the antebellum boom town of Utica, New York, showed how the emergence of a commercial bourgeoisie relied on the institution of family practices of domesticity. Christine Stansell, by focusing on the laboring poor, opened a new vein of analysis revealing the aggressively reformist uses of the discourse of domesticity and the ways that middle-class women and men used it both to clarify their own cultural identity and to attempt to transform the poor into their own image. Writing in 1982, and forecasting some part of her 1986 book City of Women, Stansell began with the premise that the mid-century middle class, if "economically ill-defined," made "the ideology of domesticity ... central to its self-conception." Stansell's work, documenting vividly the prevalence of street life, scrounging,

efforts include Mark C. Carnes and Clyde Griffen, eds., Meanings for Manhood: Constructions of Masculinity in Victorian America (Chicago: University of Chicago Press, 1990); E. Anthony Rotundo, American Manhood: Transformations in Masculinity from the Revolution to the Modern Era (New York: Basic Books, 1993), and Robert L. Griswold, Falherhood in America: A History (New York: Basic Books, 1993). No one has done more to elevate the view that gender ought to be understood relationally and as a means to signify power than Joan W. Scott; see "Gender: A Useful Category of Historical Analysis," American Historical Review 91 (December 1986), 1053-76. 
and socializing among poor urban women and their families, was especially acute in showing how self-aggrandizing were the claims of white middle-class women, subjects and proponents of domesticity, who assumed that their view of the home described and included (potentially) all women. ${ }^{13}$

A weighty work of British history by Leonore Davidoff and Catherine Hall, Family Fortunes (1987), filled in the emerging portrait. Painstakingly documenting how gender beliefs and women's family practices enabled the middle class not only to establish a cultural identity and promulgate its worldview but to consolidate its assets, Davidoff and Hall challenged, perhaps more effectively than historians of the United States, the nineteenth-century rhetoric that the home was a private realm, separate from the public world in which men pursued wealth and power. ${ }^{14}$ Aside from dovetailing the making of class and gender identities, women's historians unsettled the nineteenth-century notion that the home was separate from the public world by showing the continued involvement of households in economic production and thus the engagement of women, including wives, in work destined for the market. Joan Jensen's work was signal here, but many scholars contributed to the effort to reveal and confute the wishful thinking involved in nineteenth-

13. Mary P. Ryan, Cradle of the Middle Class: The Family in Oneida County, New York, 1790-1865 (New York: Cambridge University Press, 1981); Christine Stansell, "Women, Children, and the Uses of the Street: Class and Gender Conflict in New York City, 1850-1860," Feminist Studies 8 (Summer 1982), 309-35 (quotation from 310), and City of Women: Sex and Class in New York, 17891865 (New York: Knopf, 1986).

14. Leonore Davidoff and Catherine Hall, Family Fortunes: Men and Women of the English Middle Class, 1780-1850 (Chicago: University of Chicago Press, 1987); cf. Stuart M. Blumin, The Emergence of the Middle Class: Social Experience in the American City, 1790-1900 (New York: Cambridge University Press, 1989), esp. 138-91. 
century speakers' insistence that "woman's sphere" was a "separate sphere." 15

Jeanne Boydston's Home and Work: Housework, Wages, and the Ideology of Labor in the Early Republic (1990) offered the most sophisticated approach to this problem. ${ }^{16}$ Ingeniously documenting the constancy and economic value of working-class and middle-class women's unpaid labor of housework, she argued persuasively that this labor by women, far from being extrinsic to the process of capitalist industrialization, was essential to it. Yet the economic content and value of housework were rendered invisible by the discursive mandate of woman's "separate" sphere. Boydston's approach developed far more systematically my assertion in The Bonds of Womanhood that women occupied at home were not leisured, and she confronted head-on the dogma that such occupation was not economically productive. Her argument for the purposive "pastoralization" of housework-the didactic conversion by which woman's work at home was understood as a way of being rather than as labor-extended the argument of my second chapter, which analyzed the "central convention" of domesticity, the discursive contrast between home and world and the way it constructed a "vocation" for womanhood.

While seeking material reasons for the credibility of the rhetorical onslaught, in The Bonds of Womanhood I aimed

15. See Joan Jensen, "Cloth, Butter and Boarders: Women's Household Production for the Market," Review of Radical Political Economics 12 (Summer 1980), 14-24, and Loosening the Bonds: Mid-Atlantic Farm Women, 1750-1850 (New Haven: Yale University Press, 1986); Elizabeth H. Pleck, "Two Worlds in One: Work and Family," Journal of Social History 10:2 (1976), 178-95; Thomas Dublin, "Women and Outwork in a Nineteenth-Century New England Town," in The Countryside in the Age of Capitalist Transformation, ed. Steven Hahn and Jonathan Prude (Chapel Hill: University of North Carolina Press, 1985); Nancy Grey Ostend, "'She Helped Me Hay It as Good as a Man,' " in To Toil the Livelong Day, ed. Carol Groneman and Mary Beth Norton (Ithaca: Cornell University Press, 1987).

I6. New York: Oxford University Press, 1990. 
not to concretize but to problematize and explore the consequences of early nineteenth-century rhetoric posing home and world as antitheses. ${ }^{17}$ From the quotation marks around "woman's sphere" in the subtitle to numerous usages such as canon, doctrine, ideology, convention, and rhetoric to denote domesticity, I employed various means to indicate this. Likewise, my recognition of the legal doctrine of coverture, which meant that wives' labor and property-their very beings in the eyes of the law-were their husbands' to command, infused my presentation of domesticity. The rhetorical claim that wives could create a haven at home because they were "disinterested," having no individual economic interests to pursue, for instance, reflected and reinforced coverture's award of wives' labor power to their husbands while it appeared to differentiate the values of the home from those of the marketplace. I was convinced that the mistaken image of women at home as leisured came from aligning three pairs of polarities that were not really congruent-woman/man, home/world, and leisure/work-but I did not explore this at length nor envision the tremendous interest in the gender dimensions of the private/public distinction that would follow in the 1980s. Through that decade, historians grappled with the question whether the categories of "private" and "public," their available meanings historically inflected by the rhetoric of separate spheres, were

17. Carroll Smith-Rosenberg's important essay "The Female World of Love and Ritual: Relations between Women in Nineteenth-Century America," Signs 1 (1975), 1-29, impressed many readers with the notion that nineteenth-century men and women inhabited separate worlds (at least in a psychological and emotional sense), and some may have merged Smith-Rosenberg's portrayal of a "female world" with mine. I tried to stress, however, that the "bonds of womanhood" were constructed as complementary to (rather than separate from) men's presence and authority. I benefitted greatly from Smith-Rosenberg's early essay, "Beauty, the Beast, and the Militant Woman," American Quarterly 23 (1971), but "The Female World" was published after I had already written The Bonds of Womanhood. 
usable in the late twentieth century or had to be discarded as artifacts, themselves, of the discourse of domesticity. ${ }^{18}$

Historians such as Nancy Hewitt writing during the 1980s renovated my view by insisting that women such as those I had discussed were at least as much wedded, figuratively as well as literally, to men of their own class as to the general category of womanhood. ${ }^{19}$ No doubt because I was so interested in gender formation and the development of hegemonic notions of womanhood, I succumbed to some extent to the universalizing pretensions of the discourse of domesticity-tending, that is, not to look for alternatives to the set of ideas and practices emanating from the prosperous white middle class, and assuming too broad a reach for the shared womanhood that my subjects envisioned. If historians of the 1970 s disaggregated gender from other considerations to make it visible, their successors refocused attention on the way that gender meanings were inflected by and constituted within economic status, class, racial, and ethnic identity. Gender discourse thus could be understood as an arena of selfdefinition and of conflict not only between men and women of the white middle class or another specified ethnic or class group, but also, for example, between African-American slaves and their white masters, or Irish Catholic immigrants and Protestant providers of outdoor relief. Dissonance and subversion within the discourse of domesticity, the multiple possibilities for action, and certainly for consciousness of oneself as a woman or man appeared far more extensive as a

18. Linda K. Kerber's essay, "Separate Spheres, Female Worlds, Woman's Place: The Rhetoric of Women's History," Journal of American History 75 (June 1988), 9-39, summed up late-1980s restiveness with separate spheres rhetoric. Cf. Carole Pateman, "Feminist Critiques of the Public/Private Dichotomy," in Public and Privale in Social Life, ed. S. I. Benn and G. F. Gaus (London: Croom Helm, 1983), pp. 281-303.

19. Hewitt, "Beyond the Search for Sisterhood: American Women's History in the 1980s," Social History 10:3 (October 1985), 299-321. See also her Women's Activism and Social Change: Rochester, New York, 1822-1872 (Ithaca: Cornell University Press, 1984). 


\section{result of attention to complex self-definitions. ${ }^{20}$}

More recent historians have shown how groups denied access to the material conditions of domesticity have sought its prerogatives as a form of resistance to the preponderant power of the propertied classes: thus ex-slave families collaborated in denying the field labor of their wives and mothers to white landowners, so that these women could work in their own homes; and industrial workers in the late nineteenth century asserted their right to a family wage earned by the male head of household. ${ }^{21}$ These intended subversive as well as dominant uses-which indicate the different ways a discourse can be grasped and reinterpreted-had the ironic effect of deepening the hold of domesticity as an American practice and worldview, even as they complicated what the discourse meant. The same can be said of middle-class women's redeployment of domestic values as they tried to exert social power through reform organizations such as the Woman's Christian Temperance Union and women's clubs. Such women's groups adopted ruling presuppositions about maternal goodness and guidance, turning them toward so-

20. Especially important here was scholarship on southern and working-class women, such as Susan Levine, "Labor's True Woman: Domesticity and Equal Rights in the Knights of Labor," Journal of American History 70:2 (1983), 323-40; Suzanne Lebsock, The Free Women of Petersburg: Status and Culture in a Southern Town, 1784-1860 (New York: Norton, 1984); Deborah Gray White, Ar'n't I a Woman? Female Slaves in the Plantation South (New York: Norton, 1985); Ruth Milkman, ed., Women, Work and Protest (Boston: Routledge, 1985); Dolores E. Janiewski, Sisterhood Denied: Race, Gender and Class in a New South Community (Philadelphia: Temple University Press, 1985); and Elizabeth FoxGenovese, Within the Plantation Household (Chapel Hill: University of North Carolina Press, 1988).

21. See, for example, Martha May, "Bread before Roses: American Workingmen, Labor Unions, and the Family Wage, ${ }^{n}$ in Milkman, ed., Women, Work and Protest, pp. 1-21, and Jacqueline Jones, Labor of Love, Labor of Sorrov: Black Women, Work, and the Family from Slavery to the Present (New York: Basic Books, 1985), pp. 44-78, the latter especially effective in making the point that freed slaves' own reasons rather than "imitation" of whites motivated their pursuit of domesticity. 
cial and public goals in the effort to create what Sara Evans has called a "maternal commonwealth."

It was the genius of the nineteenth-century bourgeoisie to make the contingent family pattern of domesticity seem necessary and, without acknowledging contradiction, to accept it as natural while trumpeting it as the height of civilization. Having been a value and a sign of a particular class, forwarded by that class as a universal norm, the discourse of domesticity evolved (especially during the half-century of national consolidation after the Civil War) into a national standard, used to understand, measure, and invite in or cast out cultural and racial groups such as Mormons, Asians, and freed blacks, as well as diverse Europeans. It figured prominently in philanthropy and reform of many sorts. Stansell pointed out how moral and social reformers at mid-century attacked the problem of urban poverty in the language of domesticity, intending to impress upon the poor who peddled and scavenged on city streets that children should be off the streets, the wife and mother at home, the husband and father at work. Similarly, both government authorities and Christian missionaries cited Native Americans' divergence from the values of domesticity to justify intervention, renovation, or coercive actions. The "solution" devised by reformers in the 1870 s and 1880 s to the "Indian problem" involved land allotment to individual family households, making the men property owners and the women housekeepers. Throughout the surges of immigration in the late nineteenth and early twentieth century, immigrants' adherence to standards of domesticity was judged a principal criterion of their suitability for American life. Whether they were Russian Jews in New York City or Mexican Catholics in California, the prescription they were handed for fitting in and gaining the attributes of citizens looked 
remarkably similar. Likewise, American foreign missionaries applied their own domestic values to the "heathen" abroad, and saw evidence of Christianization in the attainment of domesticity. ${ }^{23}$

Indeed, the very capaciousness of the discourse of domesticity-the many endeavors that have been justified or enacted in its name-may throw doubt on a proposition of The Bonds of Womanhood, that consciousness of womanhood fostered by domesticity underlay the emergence of women's rights advocacy. If domestic discourse has had so many incarnations, should one then expect feminism to be nurtured in every case? I think not, and the book does not point in that direction: it sees group-consciousness of womanhood as only a precondition for demanding women's rights, not an automatic route toward that destination. The double edge of such group-consciousness, and how it could lend itself to conservative policing of boundaries around feminine propriety (especially within the formative environment of evangelical Protestantism) is a minor theme in The Bonds of Womanhood. Mary P. Ryan more forcefully made the point in 1979, as the New Right forced itself on contemporary poli-

23. See, for example, Robert Trennert, "Educating Girls in Nonreservation Boarding Schools, 1878-1920," Western Historical Quarterly (July 1982), 271-90; Theda Perdue, "Southern Indians and the Cult of True Womanhood," The Web of Southern Social Relations, ed. Walter J. Fraser, Jr., et al. (Athens: University of Georgia Press, 1985), pp. 35-51; Gwendolyn Mink, "The Lady and the Tramp: Gender, Race, and the Origins of the American Welfare State," in Women, the Stale, and Welfare, ed. Linda Gordon (Madison: University of Wisconsin Press, 1990), pp. 92-122, and George Sanchez, “'Go after the Women': Americanization and the Mexican-American Woman, 1915-1929," in Unequal Sisters, ed. Vicki L. Ruiz and Ellen Carol DuBois (New York: Routledge, 1994), pp. 284-97; Joan Brumberg, "Zenanas and Girlless Villages: The Ethnology of American Evangelical Women, 1870-1910," Journal of American History 69 (1982), 347-71; Patricia Grimshaw, Paths of Duly: American Missionary Wives in Nineteenth-Century Hawaii (Honolulu: University of Hawaii Press, 1989); Peggy Pascoe, Relations of Rescue: The Search for Female Moral Authority in the American West, 1874-1939 (New York: Oxford University Press, 1990). 
tics, and feminist scholars since have taken up the question of conservative and anti-feminist women's political activism. ${ }^{24}$

Also, it is not incidental that The Bonds of Womanhood finds the potential for the critical edge of women's rights' advocacy among women of the culturally dominant white middle class. It seems to me that the women most likely to organize around the "disabilities" of sex in a representative democracy are those who share the privileges of dominant men with respect to ethnicity, race, wealth, religion, and so on, while women of the poor and of oppressed minorities are likely to feel goaded by other social resentments. ${ }^{25}$ For some time, historians have asserted that women's rights advocacy in the United States has been dominated by white middleclass women. ${ }^{26}$ Yet, obviously, it is only a small minority of

24. See Mary P. Ryan, “The Power of Women's Networks: A Case Study of Female Moral Reform in Antebellum America," Feminist Studies 5:1 (Spring 1979), 66-86; Rebecca E. Klatch, Women of the New Right (Philadelphia: Temple University Press, 1987), Gender $\mathcal{G}$ History: Special Issue on Gender and the Right 3:3 (Autumn 1991); Kathleen M. Blee, Women of the Klan (Berkeley: University of California Press, 1991).

25. See my The Grounding of Modern Feminism (New Haven: Yale University Press, 1987); and "What's in a Name? The Limits of 'Social Feminism,' or, Expanding the Vocabulary of Women's History," Journal of American History 76 (December 1989), 809-29.

26. Alice Rossi raised the issue in terms of "status politics" in her stimulating early essay "Social Roots of the Woman's Movement" in her collection, The Feminist Papers (New York: Columbia University Press, 1973), pp. 241-81. Both William O'Neill, Everyone Was Brave: A History of Feminism in America (Chicago: Quadrangle, 1969), and Aileen S. Kraditor, Ideas of the Woman Suffrage Movement, 1890-1920 (New York: Columbia University Press, 1965), acknowledged "middle-class" predominance in the women's rights movement, without probing or specifying it. For more serious consideration of class issues in nineteenth-century women's movements, see Ellen Carol DuBois, Feminism and Suffrage: The Emergence of an Independent Women's Movement in America, 1848-1869 (Ithaca: Cornell University Press, 1978); William Leach, True Love and Perfect Union (New York: Basic Books, 1981); Barbara Epstein, The Politics of Domesticity (Middletown, Conn.: Wesleyan University Press, 198I); Steven M. Buechler, The Transformation of the Woman Suffrage Movement (New Brunswick, N.J.: Rutgers University Press, 1986); Lori D. Ginzberg, Women and the Work of Benevolence (New Haven: Yale University Press, 1990). 
that class who are thus motivated rather than complacent. Indeed, as Nancy Hewitt, Ellen DuBois, and others have shown, the inspiration for those white middle-class women who have spoken out on the injustice of sex inequality can often be traced to their perception of or participation in struggles against race or class injustice; they may be drawn to women's rights because of their particular placement within middleclass ranks, or because they admire the leadership of working-class women, or see an analogy between sex and race exclusion, and so on. ${ }^{27}$ There are many paths to (as well as away from) feminism, better understood now than when I wrote this book not only because of the work of historians but also because of the generational changes within the late twentieth-century women's movement. Yet such magnification of understanding does not undo the insight in The Bonds of Womanhood that there is likely an important relationship among an elaborated discourse of domesticity, the sex-consciousness that women at the center of it thereby gain, and the potential for women's rights activity. I continue to find this insight productive, without drawing the conclusion that this is the only dynamic of feminist awareness. For instance, rather than presuming that the relationship between the 1950s "feminine mystique" and the 1960s upsurge of feminism was one between repression and rebellion, I would guess that the 1950s emphasis on women's difference from men was (paradoxically) an enabling factor, one that exploded the interwar illusion that men and women had achieved social parity.

Like any work of human creation, The Bonds of Womanhood cannot escape the specificity of its origin. If it speaks of

27. See, for example, Sara M. Evans, Personal Politics (New York: Random, 1979); Meredith Tax, The Rising of the Women (New York: Monthly Review Press, 1980); Nancy Hewitt, "Feminist Friends: Agrarian Quakers and the Emergence of Women's Rights in America," Feminist Studies 12 (Spring 1986), 27-49; Ellen Carol DuBois, "Working Women, Class Relations, and Suffrage Militance," Joumal of American History 74 (June 1987), 34-58. 
the early 1970 s as well as of the early nineteenth century, perhaps that will reemphasize one of the things it intended to communicate: that notions of gender are continually mutable-historical products always in the making and remaking-in every time and place being forged, disseminated, contested, reworked, and in some guise reaffirmed.

Nancy F. Cott January 1997 